\begin{tabular}{c} 
Volume and Issues Obtainable at Center for Sustainability Research and Consultancy \\
Sustainable Business and Society in Emerging Economies \\
ISSN: 2708-2172 \& (E): 2708-2504 \\
Volume 3: Issue 3 September 2021 \\
CSRC \\
Journal homepage: $\underline{\text { www.publishing.globalcsrc.org/sbsee }}$ \\
\hline
\end{tabular}

\title{
The Mediating Relationship of Political Skills between Political Personality Traits and Career Success of Educators in Punjab, Pakistan
}

Muhammad Farooq Rehan, Assistant Professor, College of Commerce, Government College University, Faisalabad, Pakistan

Raheel Mumtaz, Assistant Professor, College of Commerce, Government College University, Faisalabad, Pakistan

*Quaisar Ijaz Khan, Assistant Professor, College of Commerce, Government College University, Faisalabad, Pakistan

Samreen Iqbal, M. Phil Scholar, College of Commerce, Government College University Faisalabad,

Pakistan

Corresponding author's email address: drqikhan@gmail.com

\begin{tabular}{l}
\hline ARTICLE DETAILS \\
\hline History \\
Revised format: Aug 2021 \\
Available Online: Sep 2021
\end{tabular}

Keywords

Political Personality Traits, Political Skills, Career Success, Punjab, Educators

JEL Classification

P16, P26

\section{ABSTRACT}

Purpose of the Study: The study explored a unique framework developed from social cognitive career theory by hypothesizing the mediating relationships to test.

Design/methodology/approach: The statistical model measured mediating relationship by using SPSS version 23 and Process version 4.0 to summarize the findings. Total 400 questionnaires were distributed in different secondary schools of Punjab, Pakistan from which 317 were returned and 289 were found fit for analysis. The study is cross sectional in nature and data were collected physically and online as well through self-administrative questionnaire.

Findings: The results can be generalized as all the secondary schools follow the same rules and regulations. As for the results are concerned the mediating relationship of political skills between political personality traits and career success is significant.

(C) 2021 The authors, under a Creative Commons Attribution-

NonCommercial- 4.0

Recommended citation: Rehan, F. M., Mumtaz, R., Khan, I. Q., and Iqbal, S. (2021). The Mediating Relationship of Political Skills between Political Personality Traits and Career Success of Educators in Punjab, Pakistan. Sustainable Business and Society in Emerging Economies, 3(3), 411-420.

\section{Introduction}

Teacher is a person who devotes his time towards the academic and professional development of student for becoming a leader in his future. In Pakistan teachers have to face many problems that become a hurdle on their carrier growth or success. Management wants to take different work other than the workload of teachers (Alsughayir, 2021; Ilyas \& Rafiq, 2012). Teachers bear a lot of stress and workload of school which is a very critical issue in this regard. Extraordinary efforts expected from teachers by the management authorities shows negative results when teachers became unable to show them performance according to the wishes or expectations of the management (Akhtar \& Kalsoom, 2014; Karuhanga, 2015). 
Some important problems are given such as favoritism is a major cause that becomes very common now a days in private and government institution. It means to favor the person for job who is familiar and favorite to the management (Alfes, Shantz, Truss, \& Soane, 2013; Azeem, Rubina, \& Paracha, 2013; Javed, Abrar, Bashir, \& Shabir, 2014). In this regard non-capable persons will hold the jobs as compared to deserving and capable person. It will also affect the working environment conditions in an organization because relation will exist there (Bashir, Bashir, Rana, Lambert, \& Vernallis, 2021). Pay scale and salary slab is also another problem. Every teacher or employee in teaching organization must think that he or she might have handsome amount as a reward. Low packages will demotivate employee and it may in return enhance the chances of turnover (Chunyu \& Liping, 2021). It will become difficult to hold or retain employees. Salary slab must be focused because it will enhance the performance and business activities as well as the reputation in competitive market (Masood, 2019).

Another issue in this regard is that increment on salary is not according to the requirement of teacher. A new comer teacher's salary will be high as compared to old ones. This shows a negative impact on old employee, he or she will demotivate due to this discrimination (Imran, Arif, Cheema, \& Azeem, 2014). Over workload and stress is a major issue regarding this situation. The strict and hard rules designed by the principal and management when imposed on employee it will leave a negative impact on staff because it have been noticed that if these rules followed by management or principal what will happen? are they willing to follow or obey these hard rules for themselves or they should be considered that these persons are human being and they need some rest and friendly working environment (Nayyar \& Naqvi, 2013).

Sometimes parents are directly blamed the teachers that they are liable for the enactment of student, and they thought teachers don't have right to say something harshly to the students basically parents must have vision of that teachers are also spiritual parents of students. The basic purpose of this attitude of teacher is to guide the student to become a responsible citizen (Nelofer, 2013). Organization justice if positive it will prove best for employees and if it becomes negative it will destroy the peace in an organization. Merit based judgment will discriminate the high performer and low performer (Lee \& Lee, 2015; Pak \& Kim, 2018).

Friendly working environment can play a vital role in any organization because it is a condition where employee can work easily. Because in this environment employee can work with great passion and enthusiasm. He or she can work with free mind and out of stress. Another advantage is that he or she can communicate his or her employer or management easily (Saher, Bibi, Farmanullah, \& Abbas, 2014).

However, the teachers' satisfaction from his own work is important and the career success of the teacher is desired and necessary for organizations as well as for the individuals. As the success of an individual contributes towards organizational success. (Quaisar, Shukor, \& Soffian, 2016a).

Therefore, the study intends to reinforce the mediating relationship of political skills between political personality traits and career success of educators working in Government owned schools.

\section{Review of Literature}

The purpose of this section is to analysis present theoretical as well as empirical literature that analyzes the factors that influence careers. The review seeks to find and show the progression of literature in career success from an organizational political perspective. This review has been conducted to provide the background knowledge essential for this research and try to identify the gaps in the literature that require further research. Furthermore, this literature review also attempts to conceptualize, find, and show the progression of studies in the area organizational politics and to identify the antecedents and impact of organizations politics. 


\section{Conceptualizing of Career Success}

A review of the literature revealed that, over time, career research has become a popular focus of management research. Individual and management of the organization both can get benefit from career success. Researchers have examined this topic from many different perspectives. For example, career success, career commitment, career plateau, career outcome. Career expansion is a continuing procedure by which individuals progress through a chain of steps. The structure of a school principal's career path specifies that only a minority of teachers have the chance to make it a priority at the top. Before a school principal is promoted to the job, he or she has to undergo the teaching career stage. Therefore, an idea of Professional achievement is flattering a prevalent investigation in the perspective of organization. Career achievement is a method for persons to accomplish their needs for success and authority. Both researcher and individual can get benefit from the research. Different policies can be developed by individual if he/she has the knowledge of career success (Pavlin \& Svetlik, 2014).

Numerous theories help as the theoretic basis supporting the schoolwork of career success. However, many of the past research studies examined career success using variables without considering the theoretically based variables. This social cognitive career theory assumes that everybody has different quantity of capital or asset. Investment in potential workforce is highly desired and can get more privileges as compared to others. It will also enhance the performance of individuals' and may result in organizational performance (Tan, 2010).

Career success is a fusion of two perspective objective commonly deemed as extrinsic in nature and subjective that reflects intrinsic in nature. A person getting high-ranking, enjoying superior position in any organization and with being paid better is objectively assumed progressing in career and attaining career success with an extrinsic perspective ((Ng \& Feldman, 2010; Tan \& Yahya, 2013; Traavik \& Richardsen, 2010). Whilst the person enjoying the superior position in organization withdrawing a good salary might be at the cost of physiological, psychological and socialization cost. How can a person be satisfied with his/her professional attainments on the cost of keeping him/herself away from his friends, family, and physiological needs? Therefore there is a consensus of researchers that the satisfaction of someone from his/her attainments are purely intrinsic in nature and known to him/her only (Quaisar, Shukor, \& Soffian, 2016b; Quaisar et al., 2016a).

An examination of the relevant literature shows that several factors influence individual career success. Career success can be predicted by different factors. It can provide a way to predict those factors which are relevant to the career success. Organizations an attention in recognizing the features that envisage career success in respect to efficiently select and develop high-potential teams to work in their organization (Wesarat, Sharif, \& Majid, 2014).

Several categories of the factors of career success emerged in the literature. In sum, the determinants of career success could be identified and organized into two different major categorizations: (a) individual attributes and (b) organizational structure. Many models of career success propose that individual factors play important roles in achieving success. Thus, the purpose of the following literature review is to examine the individual attributes of leaders that have been used in the previous studies (Kreng \& Huang, 2009; Naseer \& Jadoon, 2015).

The scientific studies of leadership in organization literature began by concentrating on a leader's trait study approach. This trait approach theory concluded that individuals are born with or without the trait for leadership. It was assumed that there were distinctive physical and psychological characteristics of leaders to which the leader behavior can be attributed. Many leadership studies have related leader traits features such as physical presence, nature, aptitude, skill, and biographical (age, gender, marital status) factors with leader effectiveness and organizational outcomes (Choi, 2010). Hence, an individual difference approach is the focus of this study. This research is in line with the suggestion by Judge et al. (2004) that individual attributes exert a stronger influence on career success compared to other factors. 


\section{Political Personality Traits}

Personality is a stable cognitive and behavioral pattern over time and across situations and is made up of various traits (Busby, Gao, \& Shidore, 2018; Sanchez-Ruiz, Mavroveli, \& Poullis, 2013). Therefore, it is sensible to expect that personality influences personal values and approaches and, hence, relates to career outcome. In the literature, the effects of individual personality on career outcome have been studied extensively (Nabi, 2001; Seibert, Sargent, Maria, \& Kiazad, 2016; Spector, Fox, \& Domagalski, 2006). As suggested in earlier studies on personality traits, here is stout theoretical basis to suggest that temperament variables should be comprised in models of career success. Individual characteristics such as personality traits and general intellectual aptitude, intelligence emotional and interpersonal relationships have been shown to influence career success (Judge \& Ilies, 2004; Poon, 2004; Ter Bogt \& Scapens, 2012). Researchers taking an approach in research have underlined the effect of a temperament trait on job approaches and other career behaviors. There have been inconsistent findings in the personality and career success literature. For example, Judge, et al. (1999) longitudinal study demonstrated that personality traits had a significant influence in both dimensions of career success. However, their longitudinal study showed that a proactive personality is significantly related to career satisfaction (Seibert et al., 2001). In today's working environment it is right to say that politics become fact in an organizational setting. It can destroy the flow of work of organization's performance. Politics can play a vital role near the smooth regulations of organization's environment. It can create potential career success for an individual. Organizational scientists have offered many different definitions in attempts to conceptualize organizational politics. Their definitions consist of combination elements: formal and informal, sanctioned and non-sanctioned, self-interest and non-self-interest, and a focus on the use of power and effect. Use of power or authority is to obtain the desired objective. Mintzberg described organizations as "political arenas" and recommended four forms of the political arena in an organization: conflict, instable association, politicized organization, and complete political ground.

In this present study, organizational politics has been referred to the individual influence actions, perceptions, and behavior at the individual level, which are directed to furthering self-interest, are informal, and are not prohibited by the organization. However, the theoretical basis for explaining the organizational politics phenomena in organizations is discussed. According to this model, the organizational influence contains of four factors: (a) centralization, (b) formalization, (c) ranked level, and (d) span of control (Ferris, Russ, et al., 1989). Centralization, hierarchical level, and distance of control have a direct positive relationship, but formalization has an adverse relationship with perceived structural politics. Job/work environmental influence factors, job autonomy, job variety, feedback, and advance opportunity have a negative relationship with organizational politics (Ferris, Russ, et al., 1989). Women, older age workers, those with a Machiavellianism personality, and high self-monitor view the work environment more politically (Ferris, Russ, et al., 1989). Researchers have intensely examined the outcome variables of organizational politics in organizations (Jaewon \& Riccardo, 2011; Rashid, Islam, \& Ahmer, 2019). Previous studies showed that organizational politics have both beneficial effects and detrimental effects. Ammeter et al. (2002) proposed a political theory of leadership that specifies the consequences of the leader's political behavior on leader effectiveness. According to Ammeter et al., a leader's organizational politics behavior influences his or her self-interest outcome including performance evaluation, promotion and mobility, compensation, and power and leader reputation.

\section{Organizational Political skills as a Moderator}

Few studies have focused on organizational politics as indirectly influencing the organizational outcomes. The acuities of organizational politics as situational variables act as moderators of the predictor's organizational outcomes relationship. Previous researchers have reported that organizational political skills act as a moderator variable (Harrell-Cook et al..1999; Harris, James, \& Boonthanom, 2005; Hochwarter et al., 2000; Hochwarter, James, Johnson, \& Ferris, 2004; Kacmar, Bachrach, Harris, \& Zivnuska, 2010; Zhang \& Lee, 2010). The interaction of organization politics and personal attributes is likely to provide greater insight into the prediction of career success. 


\section{Research Design and Methodology}

The school principals' career success is the dependent variable of the study and is defined as the optimistic emotional and work-related consequences one has gathered because of skills through the period of his or her working life (Judge et al., 1995). Career success is a multidimensional construct comprised of both extrinsic and intrinsic dimensions. Therefore, in this study, intrinsic career success has been measured. Personal perspective has been found to affect individual career success. Personal characteristics factors were independent variables in the study. Nevertheless, Political personality traits (independent variable), Political skills (mediating variable) and Career success (dependent variable) are involved in this study.

Political Personality Traits: Political personality traits refer to the energetic and prepared set of features of a person that exclusively stimuli his/her thoughts, incentives, and actions that are used to control and/or influence others (Christie \& Geis, 1970). The current study strived for highlighting the political personality traits in organizational settings of Pakistan.

Political Skills: Political skill denotes to the aptitude to comprehend others at work efficiently and to use such information to stimulus others to performance in habits that improve one's personal and/or structural objects. It has been recommended that political skill as an important forecaster of subjective career success as mediating variable.

As the study is primary in nature and cross-sectional data has been used, the purpose of the study is to test the social cognitive career theory rather than to develop the new one. The proposed theoretical model for this study represents and attempts to inspect the predictors of the career success empirically. Grounded on the existing theories, the literature review, the notional outline, and the research question, four hypotheses in alternate forms are proposed.

\section{Research Design}

The research design is an overall plan on how a research study is to be completed through the operational variables that can be measured, sampled, and data collected for testing the hypotheses (Sekaran, 2000). A research design will answer the research questions. This research study assumed the cross-sectional statistical or arithmetical study approach with a survey questionnaire as the main tool for data collection. The primary sources of data for this study were collected from school principals'/vice principals and coordinators as respondents. The survey questionnaire was used in this study was adopted from different established measuring instrument having better Cronbachs' Alpha, a sign of reliability. Pakistan's educational administration at the secondary school level is managed by a principal. They are top managers and senior level managers in school management level. The positions enable them to be promoted for higher designation on the basis of their performance. Thus, the population utilized in this study consists of school principals who serve in public sector's secondary schools in Pakistan.

\section{Sampling Method and Sample Size}

Sampling includes a process that uses a portion of a population to assume regarding the whole population. Concurrently one drop of blood can represent whole body for diagnosing purposes rather than testing the whole blood. The Probability sampling technique has been applied, where every group of people has a possibility to be designated. The sample involved in this study was selected by a proportionate stratified random sampling procedure. Stratified sampling ensures the sample is chosen according to location. The stratified sampling method reduces the sampling error in such a way that distinguished subcategories within the population are represented in the sample in the similar quantity as they exist in the population. Data through self-administrative questionnaire were collected personally and online as well.

\section{Questionnaire Design}

The questionnaire was settled in English originally to ensure that the contributors were able to respond 
comfortably to the questions. However, since all the participants in this study have high qualifications (at least graduate degrees), language is presumed not to have much effect on their ability to comprehend questions. Section (a) deals with demographic factors, section (b) deals with different items as scale to measure the variables of the study such as: Career Success was measured from 05 items scale developed by Greenhaus, Parasuraman and Wormley (1990), Political Personality Traits was measured using 15 items Political Skill was measured by 16 items scale developed by Ferris, Treadway, et al. (2005). This measurement scale was used in the Asian context by some previous researchers (Poon, 2003, Rusinah et al., 2003). Total 36 items were included in the section (b) for data collection purposes. These items are good for responses as no. of items above the range of 40 to 50 are difficult for the respondents to answer honestly (Tan \& Yahya, 2013).

\section{Research Framework}

The Figure presented below represents the hypothesized model and conceptual framework for the current study in hand.

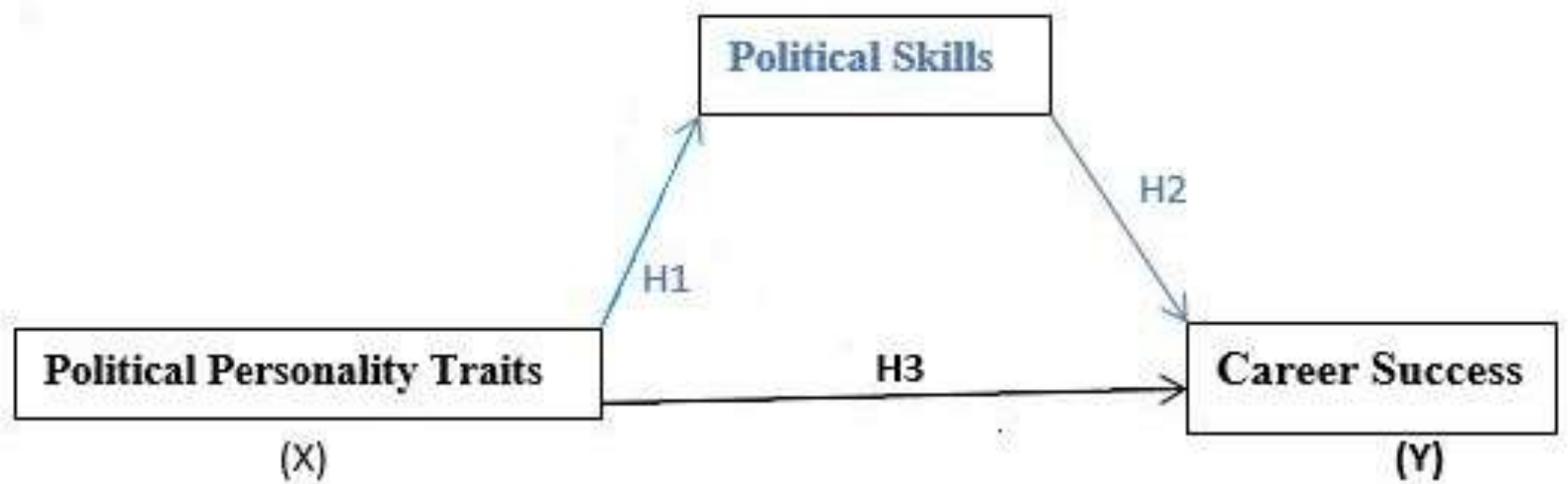

Figure: $1 \quad$ Research Framework

\section{Data Analytical Approach}

The survey data collected was examined using the SPSS Version 23. An examination of the data for scanning and cleaning was done. This involved examination for authenticity including labeling the variables and coding the items, checking the missing values, performing reliability and validity of the data, assessing normality and outliers, and then evaluating statistical molds for multivariate analysis. Some facts and figures are presented in tables for understanding as below:

\section{Data Analysis and Research Findings}

The following section deals with the statistical finding for the data collected and tested. The researchers have found the wellbeing of the data and considered it fit for analysis. The data were applied to test the moderated mediation through process version 4.0 developed by Hayes and available freely online that can be attached with SPSS latest versions. The following table are presented below developed by using the process patch: Model 05, applied and suitable for the construct. Career Success (Y), Political Personality Traits (X) and Political Skills (M) are the variables labeled and coded as: Y= Car_Suc, X= PPT and M= PS with a sample size of 289 has been tested as follow:

Table:1 Model Summary for Outcome Variable Political Skills

\begin{tabular}{lllllll}
\hline $\mathbf{R}$ & R-Sq & MSE & F & Df1 & Df2 & p \\
\hline 0.5503 & 0.3028 & 0.1008 & 129.4486 & 1.0000 & 298.0000 & 0.0000 \\
\hline
\end{tabular}

Table:2 Model Explained

\begin{tabular}{lllllll}
\hline & Coeff & Se & T & P & LLCI & ULCI \\
\hline Constant & 1.5653 & 0.1675 & 9.3447 & 0.0000 & 1.2356 & 1.8949 \\
\hline
\end{tabular}




\begin{tabular}{lllllll}
\hline PPT & 0.4873 & 0.4280 & 11.3775 & 0.0000 & 0.4030 & 0.5715 \\
\hline
\end{tabular}

The model explained the statical findings for the relationship of political personality traits and political skills. Therefore $\left(\mathrm{H}_{1}\right)$ the relationship of political Personality traits and political skills is significantly positive. Whilst the next table elaborates the findings for career success as below:

Table: 3 Model Summary for Outcome Variable Career Success (Y)

\begin{tabular}{|c|c|c|c|c|c|c|c|}
\hline & $\mathbf{R}$ & R-Sq & MSE & $\mathbf{F}$ & Df1 & Df2 & $\mathbf{P}$ \\
\hline & 0.5678 & 0.3224 & 0.1963 & 70.6688 & 297.0000 & 295.000 & 0.0000 \\
\hline & \multicolumn{7}{|c|}{ Table: 4 Model Explained } \\
\hline & Coeff & Se & $\mathbf{T}$ & & $\mathbf{P}$ & LLCI & ULCI \\
\hline Constant & 0,8802 & 0.2658 & 3.3119 & & 0.0010 & 0.3572 & 1.4032 \\
\hline PPT & 0.5692 & 0.0716 & 7.9535 & & 0.0000 & 0.4284 & 0.7101 \\
\hline PS & 0.2426 & 0.0808 & 3.0011 & & 0.0029 & 0.0835 & 0.4016 \\
\hline
\end{tabular}

The model explained the relationship of political personality traits and political skills with career success, as $t$ values for political personality traits with career success is $>1.96$ whilst on the other hand relationship of political skills with career success is significant as the $\mathrm{t}$ value is 3.0011 which is higher than 1.96 the threshold values. The model explained $r^{2}$ is $32.24 \%$, that are $67.76 \%$ portion remained undiscovered in the said model. For further evaluation the table is provided below as:

Table:5 Outcome variable Career success

\begin{tabular}{lllllll}
\hline R & R-Sq & MSE & F & Df1 & Df2 & p \\
\hline 0.5494 & 0.3019 & 0.2016 & 128.8686 & 1.0000 & 298.0000 & 0.0000 \\
\hline
\end{tabular}

Table: 6 Model Explained

\begin{tabular}{lllllll}
\hline & Coeff & Se & T & P & LLCI & ULCI \\
\hline Constant & 1.2599 & 0.2368 & 5.3196 & 0.0000 & 0.7938 & 1.7260 \\
PPT & 0.6874 & 0.0606 & 11.3520 & 0.0000 & 0.5682 & 0.8066 \\
\hline
\end{tabular}

Table:7 Total Effect of Political Personality Traits on Career Success

\begin{tabular}{lllllll}
\hline Effect & Se & T & P & LLCI & ULCI & C_CS \\
\hline $\mathbf{0 . 6 8 7 4}$ & 0.0606 & 11.3520 & 0.0000 & 0.5682 & 0.8066 & 0.5494 \\
\hline
\end{tabular}

Table:8 Direct Effect of Political Personality Traits on Career Success

\begin{tabular}{lllllll}
\hline Effect & Se & T & P & LLCI & ULCI & C $^{\wedge}$ CS \\
\hline $\mathbf{0 . 5 6 9 2}$ & 0.0716 & 7.9535 & 0.0000 & 0.4284 & 0.7101 & 0.4450 \\
\hline
\end{tabular}

Table:9 Indirect Effect of Political Personality Traits on Career Success

\begin{tabular}{lllll}
\hline & Effect & BootSE & BootLLCI & BootULCI \\
\hline PS & 0.1182 & 0.0425 & 0.0385 & 0.2078 \\
\hline
\end{tabular}

Table:10 Completely standardized indirect effect of $x$ on $y$

\begin{tabular}{lllll} 
& \multicolumn{3}{c}{ Table:10 Completely standardized indirect effect of x on y } \\
\hline PS & Effect & BootSE & BootLLCI & BootULCI \\
\hline
\end{tabular}

*Level of Confidence $95 \%$ for all confidence intervals in output

**Number of bootstrap samples for percentile bootstrap confidence intervals: 5000

\section{Conclusion and Future Recommendations}

The study brought majestic argue of testing mediating relationship of political skills between political personality traits and career success. The model was tested for the total, direct and indirect effect and found the partially significant mediating relationship with career success. The said model was tested first with outcome variable political skills which is a mediating variable. The relationship of political personality traits and political skills has been found significant with a coefficient value 0.4873 and $t$ 
value 11.3775. it reveals as significant.

Then secondly the model was tested for outcome variable career success with political personality traits and political skills having $t$ values 7.9535 and 3.0011 will is significant and then tested for $\mathrm{C}^{\wedge} \mathrm{C}^{\wedge}$ path having 11.3520 and 7.9535 respectively which is significant. When $\mathrm{C}$ and $\mathrm{C}^{\wedge}$ both the paths are positively significant it demonstrates the partially significant mediation (Baron \& Kenny, 1986; Preacher \& Hayes, 2008; Sarstedt, Hair, Ringle, Thiele, \& Gudergan, 2016). The study has few constrains such as financial and time scarcity. It is recommended for future researchers to conduct qualitative research for better results.

\section{References:}

Akhtar, M. M. S., \& Kalsoom, T. (2014). Issues of Universities' Governance in Pakistan. Journal of Elementary Education, 22(2), 81-94.

Alfes, K., Shantz, A. D., Truss, C., \& Soane, E. C. (2013). The link between perceived human resource management practices, engagement and employee behaviour: a moderated mediation model.

International Journal of Human Resource Management, 24(2), 330-351. https://doi.org/10.1080/09585192.2012.679950

Alsughayir, A. (2021). The effect of emotional intelligence on organizational commitment: Understanding the mediating role of job satisfaction. Management Science Letters, 11, 1309-1316. https://doi.org/10.5267/j.msl.2020.11.008

Azeem, M. F., Rubina, \& Paracha, A. T. (2013). Connecting Training and Development with Employee Engagement : How Does it Matter? World Applied Science Journal, 28(5), 696-703. https://doi.org/10.5829/idosi.wasj.2013.28.05.1230

Baron, R. M., \& Kenny, D. a. (1986). The moderator-mediator variable distinction in social psychological research: Conceptual, strategic, and statistical considerations. Journal of Personality and Social Psychology, 51(6), 1173-1182. https://doi.org/10.1037//0022-3514.51.6.1173

Bashir, A., Bashir, S., Rana, K., Lambert, P., \& Vernallis, A. (2021). Post-COVID-19 Adaptations; the Shifts Towards Online Learning, Hybrid Course Delivery and the Implications for Biosciences Courses in the Higher Education Setting. Frontiers in Education, 6, 310. https://doi.org/10.3389/FEDUC.2021.711619/BIBTEX

Busby, J., Gao, X., \& Shidore, S. (2018). Turning the carbon supertanker: Sectoral feasibility of climate change mitigation in China. Energy Research and Social Science, 37, 198-210. https://doi.org/10.1016/j.erss.2017.09.003

Choi, S. (2010). Organizational Justice and Employee Work Attitudes: The Federal Case. The American Review of Public Administration, 41(2), 185-204. https://doi.org/10.1177/0275074010373275

Chunyu, Z., \& Liping, L. (2021). The effect of job crafting to job performance. Knowledge Management Research and Practice, 19(2), 253-262. https://doi.org/10.1080/14778238.2020.1762517

Ilyas, M., \& Rafiq, M. (2012). Impact of Corporate Governance on Perceived Organizational Success Department of Economics. International Journal of Business and Social Science, 3(13), 178-187.

Imran, H., Arif, I., Cheema, S., \& Azeem, M. (2014). Relationship between Job Satisfaction , Job Performance, Attitude towards Work, and Organizational Commitment. Entrepreneurship and Innovation Management Journal, 2(May), 135-144.

Jaewon, L., \& Riccardo, P. (2011). Discriminant validity and interaction between perceived organizational support and perceptions of organizational politics: A temporal analysis. Journal of Occupational and Organizational Psychology, 84(4), 686-702. https://doi.org/10.1348/096317910X511197

Javed, M., Abrar, M., Bashir, M., \& Shabir, M. (2014). Effect of Perceived Organizational Politics and Core Self Evaluation on Turnover Intention: A South Asian Perspective. International Journal of Human Resource Studies, 4(2), 33. https://doi.org/10.5296/ijhrs.v4i2.5791

Judge, T. a, \& Ilies, R. (2004). Affect and job satisfaction: a study of their relationship at work and at home. The Journal of Applied Psychology, 89(4), 661-673. https://doi.org/10.1037/00219010.89.4.661 
Karuhanga, B. N. (2015). Evaluating implementation of strategic performance management practices in universities in Uganda. Measuring Business Excellence, 19(2), 42-56. https://doi.org/10.1108/MBE-06-2014-0017

Kreng, V. B., \& Huang, M.-Y. (2009). A discussion on international assignments performance and the constructing mechanism of career success development. The International Journal of Human Resource Management, 20(7), 1487-1502. https://doi.org/10.1080/09585190902983330

Lee, M.-J., \& Lee, D.-H. (2015). Effects Of Hpwss On Employee'Attitude For Korean Firms : The Mediating Role Of Human Resource Competency And The. The Journal of Applied Business Research, 31(6), 1251-1262.

Masood, A. (2019). Influence of Marriage on Women's Participation in Medicine: The Case of Doctor Brides of Pakistan. Sex Roles, 80(1-2), 105-122. https://doi.org/10.1007/s11199-018-0909-5

Nabi, G. R. (2001). The relationship between HRM, social support and subjective career success among men and women. International Journal of Manpower, 22(5), 457-474. https://doi.org/10.1108/EUM0000000005850

Naseer, Q., \& Jadoon, Z. I. (2015). Towards Understanding the Effect of HEC's Reform on Autonomy of Public Sector Universities: The Case of Punjab University. 7th South Asia International Conference, 1689-1699. https://doi.org/10.1017/CBO9781107415324.004

Nayyar, J., \& Naqvi, S. S. H. (2013). Proposed model of entrepreneurial mindset for the state government higher education institutions in Pakistan. Journal of Enterprising Communities: People and Places in the Global Economy, 7(2), 167-182. https://doi.org/10.1108/17506201311325814

Nelofer, H. (2013). Quality of private universities in Pakistan: an analysis of higher education commission rankings 2012. International Journal of Educational Management, 27(7), 775-786.

Ng, T. W. H., \& Feldman, D. C. (2010). Human capital and objective indicators of career success: The mediating effects of cognitive ability and conscientiousness. Journal of Occupational and Organizational Psychology, 83(1), 207-235. https://doi.org/10.1348/096317909X414584

Pak, J., \& Kim, S. (2018). Team Manager's Implementation, High Performance Work Systems Intensity, and Performance: A Multilevel Investigation. Journal of Management, 44(7), 2690-2715. https://doi.org/10.1177/0149206316646829

Pavlin, S., \& Svetlik, I. (2014). Employability of higher education graduates in Europe. International Journal of Manpower, 35(4), 418-424. https://doi.org/10.1108/IJM-05-2013-0104

Poon, J. M. . (2004). Career Commitment and Career Success: moderating role of emotion perception. Career Developement International, 9(4), 374-390.

Preacher, K. J., \& Hayes, A. F. (2008). Asymptotic and resampling strategies for assessing and comparing indirect effects in multiple mediator models. Behavior Research Methods, 40(3), 879891. https://doi.org/10.3758/BRM.40.3.879

Quaisar, I. K., Shukor, D. A. S., \& Soffian, D. S. S. I. (2016a). Career Success and Organizational Justice as the Potential Predictors of Perceived University Performance : A Study from Public Sector Universities of Pakistan. European Journal of Business and Management, 8(16), 131-139.

Quaisar, I. K., Shukor, D. A. S., \& Soffian, D. S. S. I. (2016b). The mediatingeEffect of career success on HRM practices and university Performance: A study from public sector universities of Pakistan. Current Economics and Management Research, 2(1), 1-8.

Rashid, M. A., Islam, T., \& Ahmer, Z. (2019). How organizational Politics Impact workers job related outcomes? In Journal of Political Studies (Vol. 26).

Saher, N., Bibi, S., Farmanullah, S., \& Abbas, S. (2014). Career Success in Pakistan : Human Capital and Social Networking. Middle East Journal of Scientific Research, 19(2), 163-171. https://doi.org/10.5829/idosi.mejsr.2014.19.2.2203

Sanchez-Ruiz, M. J., Mavroveli, S., \& Poullis, J. (2013). Trait emotional intelligence and its links to university performance: An examination. Personality and Individual Differences, 54(5), 658-662. https://doi.org/10.1016/j.paid.2012.11.013

Sarstedt, M., Hair, J. F., Ringle, C. M., Thiele, K. O., \& Gudergan, S. P. (2016). Estimation issues with PLS and CBSEM: Where the bias lies. Journal of Business Research, 69(10), 3998-4010. https://doi.org/10.1016/j.jbusres.2016.06.007 
Seibert, S. E., Sargent, L. D., Maria, L. K., \& Kiazad, K. (2016). Linking developmental experiences to leader effectiveness and promotability: self-efficacy and mentor network. Personnel Psychology, 1-41. https://doi.org/10.1111/peps.12145

Spector, P. E., Fox, S., \& Domagalski, T. (2006). Emotions, violence and counterproductive work behavior. In Handbook of workplace violence.

Tan, F. (2010). Career Planning, Individual's Personality Traits, HRM Practices as Determinants to Individual Career Success: The Role of Career Strategies as Mediator. Universiti Utara Malaysia, Alore Setar.

Tan, F., \& Yahya, K. K. (2013). The Influence of Malaysian Insurance Agents ${ }^{e e}$ Career Planning on Their Career Strategies. International Journal of E-Education, e-Business, e-Management and eLearning, (February), 23-28. https://doi.org/10.7763/IJEEEE.2013.V3.187

Ter Bogt, H. J., \& Scapens, R. W. (2012). Performance Management in Universities: Effects of the Transition to More Quantitative Measurement Systems. European Accounting Review, (January 2015), 1-47. https://doi.org/10.1080/09638180.2012.668323

Traavik, L., \& Richardsen, A. (2010). Career success for international professional women in the land of the equal? Evidence from Norway. The International Journal of Human Resource Management, 21(15), 2798-2812. https://doi.org/10.1080/09585192.2010.528662

Wesarat, P., Sharif, M. Y., \& Majid, A. H. A. (2014). A Review of Organizational and Individual Career Management: A Dual Perspective. International Journal of Human Resource Studies, 4(1), 101. https://doi.org/10.5296/ijhrs.v4i1.5331 